\title{
MANAGING THE COMPLEXITY of Climate Change
}

\author{
Shann Turnbull \\ Principal: International Institute for self-governance, Sydney, Australia
}

\begin{abstract}
This paper indicates how the knowledge of complex systems can be put into practice to counter climate change. A contribution of the paper is to show how individual behaviour, institutional analysis, political science and management can be grounded and integrated into the complexity of natural systems to introduce mutual sustainability. Bytes are used as the unit of analysis to explain how nature governs complexity on a more reliable and comprehensive basis than can be achieved by humans using markets and hierarchies. Tax incentives are described to increase revenues while encouraging organisations to adopt elements of ecological governance found in nature and in some social organisations identified by Ostrom and the author. Ecological corporations provide benefits for all stakeholders. This makes them a common good to promote global common goods like enriching democracy from the bottom up while countering: climate change, pollution, and inequalities in power, wealth and income.
\end{abstract}

\section{KEYWORDS}

Bytes, Climate Change, Common Good, Ecological Governance, Tensegrity

\section{INTRODUCTION}

The purpose of this paper is to present existing knowledge of how society might better counter the complexity of climate change. The causes and solutions of climate change are widely understood and accepted. The difficulty is how to motivate nations to take collective action. One way could be to share with citizens the knowledge required to constructively manage complex problems described as "the tragedy of the commons" [1].

These tragedies arise when different individuals or groups promote their self-interest by over exploiting common life-sustaining resources to eliminate them for everyone. The extermination of humanity on Easter Island is an example. Climate change introduces the risk of exterminating humanity.

\subsection{Avoiding Tragedies of the Commons}

For the first time the tragedy of the commons has become a global issue of human and institutional behaviour. Countless examples of such complex problems and their solutions have arisen over millenniums in the context of excessive hunting, fishing, grazing and irrigation. But their solutions have yet to be taught in graduate schools.

Political scientists Elinor Ostrom and her husband Vincent spent their lives studying how societies possessed societies have avoided the tragedy of the commons since pre-modern times. The solution did not depend upon either markets or State but by forming special types of complex

David C. Wyld et al. (Eds): CoSIT, AIAPP, SIGL, CRIS, NLPML - 2021

pp. 11-27, 2021. CS \& IT - CSCP 2021

DOI: $10.5121 /$ csit.2021.110402 
network relationships that introduce checks and balances on power elites whose actions could destroy the common good for everyone.

The Ostrom's used the language of political scientists to describe the nature of these networks as "polycentric republics" [2-9]. The decentralised and distributed communication and control architecture in such "polycentric republics" is also found in our brains [10] For this reason this form of governance can be described as "ecological" $[11,12,13]$. The knowledge on how to counter climate change becomes subjected to the natural science of governance in a way that also enriches democracy $[14,15]$.

The science of governance is grounded in contributions by Neumann [16] Shannon [17] and Ashby [18]. They indentified how to improve the reliability of data processing in respectively: decision-making, communications and control. This knowledge explains why and how nature creates complexity and how complexity can be best managed [20-27].

\subsection{The Science of Governance}

Governance science uses data as its unit of analysis. Data is routinely metered in bytes. Bytes are eight units of data called "bits". Bits are perturbations in matter and/or energy that make a difference. To minimise the materials and energy for living things to be created, developed, survive and reproduce in unknowable dynamic complex environments, evolution has developed processes for minimising the material and energy required.

According to [28] "The brain makes up 2\% of a person's weight. Despite this, even at rest, the brain consumes $20 \%$ of the body's energy". The human brain is thousands of times more efficient than the most advanced computer chips that cannot match its performance even ignoring their dependence on external power sources $[29$, p. 9].

Unlike the social science of economics that seeks to minimise the undefinable social construct of cost, the science of governance is based on minimising materials and/or energy. In this way Transaction Byte Analysis (TBA) subsumes and extends the Transaction Cost Economics (TCE) developed by Coase [30] and Williamson [31] who limited the concerns only hierarchical organisations.

TBA provides a method for analysing any type of organisation and so any type of collective activity by humans or any other specie. This is because no collective action can occur in society or nature without data processing within and between coordinating entities.

Managing problems like climate change requires knowledge of how to manage complexity. This is common knowledge with natural scientists designing self-governing automobiles and space probes.

An introduction to this knowledge for social scientists is presented in the following sections. This knowledge provides a framework presented Section 3, for understanding why current forms of markets and hierarchy are ineffectual to counter climate change. Section four suggests how tax incentives can introduce ways to introduced ecological forms of organisations and different types of markets to counter climate change. Conclusions then follow in Section 5. 


\section{LANGUAGES AND ARCHITECTURE OF COMPLEXITY}

\subsection{Tensegrity}

Words are the tools of thinking and special words are required to communicate special concepts to explain the complex communication and control architecture of ecological organisations. Mathews [32] identifies a number of special words in a review of the literature. But Mathews omitted an overarching concept of complexity called "Tensegrity". This feature is universal. It introduces inconsistent and paradoxical relationships in both physical and social structures. This allows novel relationships to arise to create new entities that are better suited in a new context while also reproducing paradoxical relationships to maintain evolutionary processes. A process inhibited by hierarchies, heterarchies or other types of relationships

Buckminster Fuller [33] coined the word "Tensegrity" by combing the words "tension" and "integrity". This concept has since been recognised by natural scientists but largely neglected by social scientists. One exception is Pound $[34,35, \mathrm{p} .11]$ who recognised its need but not its name in stating: "always have an opposition viewpoint" and at p.18 "There must always be an opposition party and the prospect of insurgency".

\subsection{The Architecture of Life and the Universe}

Scientists like Harvard biologist Ingber [36] described tensegrity as "The Architecture of life" and quantum physicist Bohm [36] described the concept in different words as the architecture of the universe. Its relevance to social organisations was identified in the $\mathrm{PhD}$ dissertation of the author $[38$, pp. 8, 69, 134].

The science of governance explains why the laws of nature found in the physical world apply to individuals, society and its institutions. This explains the similarities noted between biology and economics tabulated in $[38$, p. 68]. Ashby $[18$, p. 1] explains why identical phenomena arise in both social and natural science by observing "The truths of cybernetics are not conditional upon them being derived from another branch of science. Cybernetics has its own foundations." The remit of cybernetics is "The science of communication and control in the animal and machine" [39]. The science of governance has subsumed the science of cybernetics by being the science of communication and control in the animal, machine and social organisations.

\subsection{Holons and Holarchy}

Mathews [32] identifies a key type of structure for creating or governing complexity that Koestler [39] called a "Holon". However, Hock [41] invented his own word "Chaord" from combining the words "Chaos" and "Order". In 1970, Hock became the founding CEO of the credit card company Visa International Inc. He created an organisation that meets the test of being composed of "polycentric republics". Visa was owned by its member banks with each bank having its own board of directors within a common legal entity. Each geographic board possessed the power to issue and manage its own Visa cards to create hundreds of "polycentric republics". Each "Republic" cooperated $\sim$ competed with each other in their mutually owned legal entity.

Koestler coined the word "Holon" to describe an entity that is both a "Whole" of sub-systems and component of a larger system made up of Holons that he called a Holarchy. The Greek word for "whole" is "Holo with the suffix "on" being a component, like protons and electrons being components of an atom. Holons were what Smuts [42] and Simon [43] were describing with different words. 
Holons possess quite different properties from hierarchies as revealed by Hock's [44, p. 30] description of a Chaord that he described in two different ways:

1. Any self-organizing, self-governing, adaptive, nonlinear, complex organism, organization, community or system, whether physical, biological, or social, the behavior of which harmoniously combines characteristics of both chaos and order.

2. An entity whose behavior exhibits observable patterns and probabilities not governed by the rules that govern or explain its constituent parts.

Hock described "chaordic" in three ways:

1. The behaviour of any self-governing organism, organization, or system, which harmoniously blends characteristics of order and chaos.

2. Patterned in a way dominated by neither chaos nor order.

3. Characteristic of the fundamental organizing principles of evolution and nature.

\subsection{Other Cybernetic Approaches}

Beer [45] pioneered the application of cybernetics analysis to management. He developed the Viable Systems Model (VSM) to describe any organizational structure that can produce itself and survive in a changing environment [46]. Because of their cybernetic heritage a number of VSM features are found in Holons, but the reverse does not apply.

Beer developed VSM before the concept of "corporate governance" became a discipline recognized by social scientists ${ }^{1}$. This made VSM subject to the discretion of management. It was not hard wired into organizational constitutions as found in organizations governed by polycentric subsystems in VISA, The John Lewis Partnership in the UK or the Mondragón Corporacion Cooperativa (MCC) in Spain.

Beer [47] was aware of the concept of Tensegrity and developed a synthetic form he described as "Syntegrity" [48]. But like VSM its introduction was at the grace and favor of management. Crucially VSM does not include the concept of Tensegrity that is a defining feature of Holons. While Mathews [32, pp. 52-53] does not use the word Tensegrity, he recognizes its existence and its special beneficial attributes by describing their contrary $\sim$ complementary characteristics as a defining feature of a Holon. As examples, Mathews (pp. 41-44) refers to Holons as possessing: "Centralisation $\sim$ de-centralisation", "Bottom-up Top-down", "Autonomous integrated", "Order $\sim$ ambiguity", "Management $\sim$ leader". This last feature does not communicate a contrarian relationship like the others. A better description would be to use the words: "Subordinate $\sim$ leader" as arises for a Holon within a Holarchy.

\subsection{Tensegrity Hidden from Management Scholars}

Tensegrity naturally arises in mutual organizations from the conflicts arising within and between stakeholders. Tensions can arise between similar stakeholders, like the member banks of Visa,

\footnotetext{
${ }^{1}$ Beer met the author in Toronto on August 3, 1996, and a after reading a version of Turnbull [50] Beer advised that he had not extended his cybernetic insights to the governance of firms. Beer had been President of the World Organization of Systems and Cybernetic since 1987 and encouraged the author to publish in the Systems Science literature.
} 
and/or between different stakeholders classes. Examples of the latter are: customers, distributers, suppliers, contractors, employees, executives, shareholders and host communities. Tensegrity is mostly extinguished in centralized command and control hierarchies. This could explain why management scholars and practitioners promote collegiate and cooperative relationships that obscure even further how Tensegrity is hard wired into human behavior who represent an organizational Holon. Some scholars are aware of the benefits of contested relationships like Pound and Jensen [50, p. 852] who reported on "The failure of internal control systems".

Different types of stakeholders may possess different interests in the firm that can create tensions, but the interests of such stakeholders are not typically formerly integrated into the governance architecture of firms. When they are, they like unlikely to possess meaningful power and/or influence to create serious tensions.

The MCC is an exception with multi-stakeholders interests participating in cooperative supervisory boards [51]. How these potential tensions can be organized to create internal challenges for continuous improvements and adaptations to new risks and opportunities are raised in the next section. This begins by considering the systemic problems inherent in simply hierarchies involved in complex activities.

\section{WHY REPLACE HiERARChIES?}

The imperative to transform existing dictatorial command and control business hierarchies into polycentric networks of stakeholder republics arises because:

1. Hierarchies possess excessive exploitative powers that can corrupt their directors, managers, the business and society, [50; 852, 38, p. 115; 52, p. 9] and,

2. Humans possess limited physiological and neurological capacity to receive, process, store, process and communicates bytes, data, information, knowledge and wisdom to cope with complexity [31: p. 21], and,

3. Cybernetic laws of requisite variety that state it is impossible to:

a) Reliably communicate complexity up or down a hierarchy either simply or reliably without a requisite variety of independent cross checking channels, [17] and,

b) Reliably directly amplify control of complex variables without supplementary coregulators providing a requisite variety of regulation [18, p. 265].

The above problems means that corporate governance codes supported by the World Bank, OECD, UK, US and around the world are promoting a system of exploitative governance, that is subject to failure because business and political leaders lack knowledge of governance science. The problems are not limited to publicly traded entities but also to private firms, government owned firms and even non-profit organizations.

How ecological governance can mitigate twenty systemic problems inherent in enterprises organized as simple command and control hierarchies are outlined in Table 1. "How mimicking nature can mitigate systemic problems in hierarchies". Details are provided in academic $[12,13$, $14,20-27,38,51,53,56-61,63,64,66-70,72,74-76]$ and practitioner articles $[11,13,52,54,55$, $62,65,71,73,77]$.

\subsection{Data Processing Limitations in Hierarchies}

The practicality of firms transforming to polycentric republics is supported by their existence without any special laws in leading jurisdictions like the US, UK and Europe. A survey [78] of 
the internal architecture of stakeholder-governed corporations around the world by Bernstein [77] revealed that a common feature was a distribution of power to a number of boards and/or control centers. This suggests that the inherent conflicts of interest that can arise when workers can dismiss bosses and bosses can dismiss workers without a separation of powers do not allow such organizations to become sufficiently sustainable to be identified.

Table 1. How mimicking nature can mitigate systemic problems in hierarchies

\begin{tabular}{|c|c|c|}
\hline & Toxic problems of hierarchies & Mitigation by mimicking nature \\
\hline 1 & Society assumes top-down control is natural & $\begin{array}{l}\text { Nature uses bottom/up control \& top/down } \\
\text { guiding }\end{array}$ \\
\hline 2 & $\begin{array}{l}\text { So no education about ecological governance } \\
\text { with distributed control to simplify complexity }\end{array}$ & $\begin{array}{l}\text { Complexity simplified with almost self- } \\
\text { governing sub-systems dependent upon } \\
\text { contrary guiding }\end{array}$ \\
\hline 3 & $\begin{array}{l}\text { Unitary boards obtain absolute power to } \\
\text { identify and manage their own conflicts of } \\
\text { interest to allow absolute corruption of } \\
\text { directors, the business and society }\end{array}$ & $\begin{array}{l}\text { Shareholders appoint one board to manage the } \\
\text { business and a second to govern the } \\
\text { corporation to establish tensegrity benefits for } \\
\text { all stakeholders and society }\end{array}$ \\
\hline 4 & $\begin{array}{l}\text { Group think arises from directors captured by } \\
\text { CEO to hide risks, misconduct \& malfeasance }\end{array}$ & $\begin{array}{l}\text { Governors/guardians of stakeholder voices } \\
\text { obtain contested "requisite variety" of data for } \\
\text { checks and balances }\end{array}$ \\
\hline 5 & $\begin{array}{l}\text { Corporations can lie and/or mislead themselves } \\
\text { about director independence }\end{array}$ & $\begin{array}{l}\text { Directors independence becomes irrelevant as } \\
\text { Governors control minimized conflicts }\end{array}$ \\
\hline 6 & $\begin{array}{l}\text { Directors capture auditors who judge their } \\
\text { accounts }\end{array}$ & $\begin{array}{l}\text { Governors control auditors who judge } \\
\text { directors accounts }\end{array}$ \\
\hline 7 & Auditors lie that they are independent & Auditors kept independent by Governors \\
\hline 8 & $\begin{array}{l}\text { Accounting doctrines hide how investors get } \\
\text { overpaid beyond their investment time horizons } \\
\text { with surplus profits creating hidden sources of } \\
\text { inequality and stakeholder exploitation }\end{array}$ & $\begin{array}{l}\text { Ownership of surplus profits distributed by } \\
\text { corporations issuing shares to citizen } \\
\text { stakeholders that democratizes wealth and } \\
\text { power. Reduces the need for corporate taxes } \\
\text { and welfare programs }\end{array}$ \\
\hline 9 & Directors control advisors to shareholders & Shareholder advisors controlled by Governors \\
\hline 10 & Directors nominating themselves for election & $\begin{array}{l}\text { Director nomination by shareholders \& } \\
\text { Governors }\end{array}$ \\
\hline 11 & $\begin{array}{l}\text { Directors control their own pay after setting } \\
\text { and marking their own "exam papers" aka KPIs }\end{array}$ & $\begin{array}{l}\text { Governors determine director pay from } \\
\text { Stakeholder Key Performance Indicators } \\
\text { (KPIs) }\end{array}$ \\
\hline 12 & $\begin{array}{l}\text { Directors control reports about corporate } \\
\text { impact on the environment, stakeholders and } \\
\text { community welfare and their own governance }\end{array}$ & $\begin{array}{l}\text { Stakeholders provide guardians with reports } \\
\text { for shareholders on Governors pay, corporate } \\
\text { impacts on: stakeholders, the environment } \\
\text { and society. }\end{array}$ \\
\hline 13 & $\begin{array}{l}\text { Directors control how they are held } \\
\text { accountable to shareholders at AGMs and } \\
\text { control the voting processes on own election } \\
\text { and remuneration. }\end{array}$ & $\begin{array}{l}\text { Stakeholder nominee controls conduct of } \\
\text { AGMs. Governors determine AGM agenda, } \\
\text { location, acceptance of proxy votes, vote } \\
\text { counting, etc. }\end{array}$ \\
\hline 14 & Directors ignorant of shareholder identities, etc. & $\begin{array}{l}\text { All ultimate owners and/or controller made } \\
\text { public }\end{array}$ \\
\hline 15 & $\begin{array}{l}\text { Share trading relationships and price } \\
\text { manipulation hidden from directors and public }\end{array}$ & $\begin{array}{l}\text { No shares traded without prior disclosure of } \\
\text { any related derivatives and identity of counter } \\
\text { parties }\end{array}$ \\
\hline 16 & $\begin{array}{l}\text { Shares traded covertly by third party exchanges } \\
\text { and in "Dark pools" }\end{array}$ & $\begin{array}{l}\text { Corporations directly execute all share } \\
\text { transfers }\end{array}$ \\
\hline 17 & $\begin{array}{l}\text { Directors not held to account by various } \\
\text { stakeholder groups who may have conflicting } \\
\text { interest but on who directors rely upon to } \\
\text { improve the quality, reliability, and efficacy of }\end{array}$ & $\begin{array}{l}\text { Each common interest stakeholder group } \\
\text { obtains rights to form their own non-profit } \\
\text { associations to appoint advocates- } \\
\text { supplementary regulators/ management }\end{array}$ \\
\hline
\end{tabular}




\begin{tabular}{|lll|}
\hline & continuous operational improvements & $\begin{array}{l}\text { mentors that avoid directors and shareholders } \\
\text { being kept in a cocoon of ignorance }\end{array}$ \\
\hline $\mathbf{1 8}$ & $\begin{array}{l}\text { Directors of simple command and control } \\
\text { hierarchies lack systemic process to cross } \\
\text { check management actions and misreporting }\end{array}$ & $\begin{array}{l}\text { Directors obtain stakeholder communication } \\
\text { and control channels independent of mangers } \\
\text { to cross check integrity of operations and } \\
\text { outcome reports. }\end{array}$ \\
\hline $\mathbf{1 9}$ & Impossibility of controlling complexity directly & $\begin{array}{l}\text { Complexity controlled indirectly by } \\
\text { stakeholders }\end{array}$ \\
\hline $\mathbf{2 0}$ & Self-regulation/governance is impossible & $\begin{array}{l}\text { Self-governance shrinks costs \& size of } \\
\text { government \& compliance costs. }\end{array}$ \\
\hline
\end{tabular}

Such separations of powers need not necessarily produce polycentric republics as possessed by Visa Inc, The John Lewis Partnership or the MCC. These organizations, and especially the MCC and the Citizen Utility Boards (CUBs) established by Ralph Nader [79] in the US provide working models for constructing Figure 1. Figure 1 does not represent any existing firm with polycentric republics. It is generic discussion model to illustrate some critical elements for introducing ecological governance.

A crucial essential feature is to introduce contestability and so Tensegrity into the governance architecture of business by introducing a requisite variety of a separation of powers. This also eliminates a number of systemic toxic conflicts of interest while at the same time decomposing decision-making and communications overload of directors. Such outcomes are supported by the groundbreaking work of Persson, Roland, and Tabellini [80]. They showed how an appropriate separation of powers provides net advantages to all constituent stakeholders.

\section{Ecological governance identified by Ostrom can makes corporations a "common good" benefiting all stakeholders as wanted by worlds biggest investor (Fink 2018)}

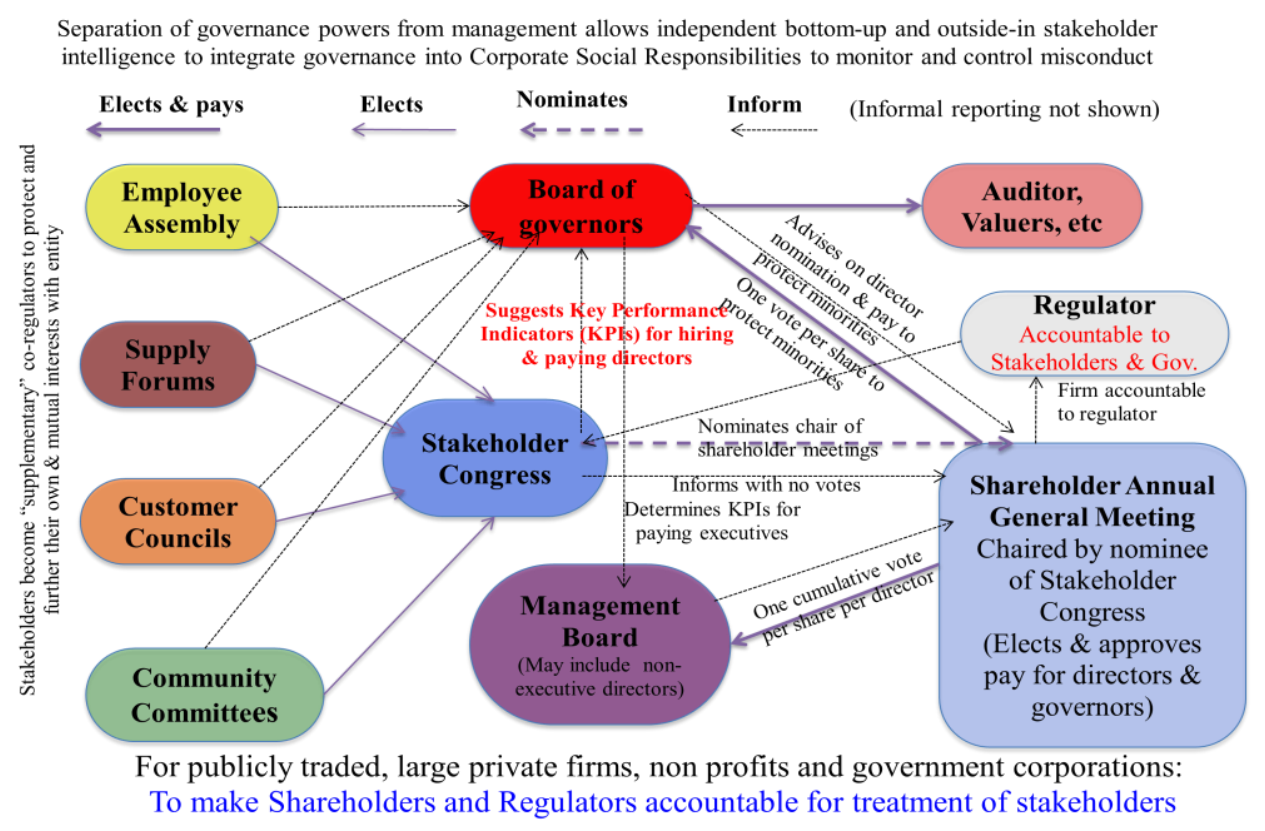

Figure 1

A complete separation of powers requires that no director who possesses the power to manage the enterprise is also involved in governing the corporate entity. The European two-tiered board would appear to achieve this objective but is compromised by supervisory boards also being 
accountable for management. Shareholders in Figure 1 are shown electing two boards and in different ways. The author has introduced this arrangement in two public companies he has founded $[60,81]$.

\subsection{Separation of Powers Limits Corruption}

A separation of the power to manage from the power to govern is typically introduced by Venture Capitalists (VCs) as a condition for their investment. This arrangement is also introduced in Leveraged Buy-Outs (LBOs). Jensen [50, p. 869] states that they are "proven models of governance structure" and "LBO associations and venture funds also solve many of the informational problems facing typical boards of directors." Legal scholar Dallas [82, 83] has presented arguments and proposals for a separation of corporate powers, as have Diermeier \& Myerson [84].

Senator Murray [85] recommended to the Australian Parliament that all publicly traded companies should be required to separate the power to manage from the powers to govern by establishing the arrangements shown in Figure 1. Murray renamed the "Corporate Senate" [60] that only had veto power over conflicts of directors' interests to be come a "Corporate Governance Board" with executive powers over any conflicts of directors interests that included managing the AGM. Figure 1 suggests that the "Stakeholder Congress" appoints the chair of the AGM to avoid directors or governors being conflicted in their accountability to shareholders and other stakeholders.

\subsection{Shareholder Primacy Subjected to Democracy by Other Stakeholders}

The arrangement in Figure 1 allows shareholders to exercise control over the appointment and remuneration of both directors and governors with information provided independently of them. Shareholders obtain access to alternative views on the ability of the enterprise to provide benefits for all stakeholders [86]. Such contestability introduces Tensegrity into the conduct of AGMs.

There is no ethical commercial reason for managers of an organization to become both overworked and conflicted by also being involved in the political process of governing the organization. US company director consultant, Ralph Ward promoted his business by publishing [65] that identifies how the arrangement described in Figure 1 can provide win-win outcomes for shareholders, directors, mangers, auditors, non-executive directors or governors and stakeholders.

Figure 1 describes, "A new way to govern: Organizations and society after Enron" [62] commissioned by the UK "Think and do tank" the New Economics Foundation as a public policy pocket book to identify an alternative to Thatcher privatization or State ownership. Columbia law professor Katharina Pistor [87] prescribed the pocket book for a course module at the Swiss International Law School [73]. The pocket book describes "A new model of corporate governance" [89] sought by the largest asset manager in the world to allow companies to provide "benefits for all stakeholders" [89]. All the 180 CEO's of the US Business Round Table who have Fink as a shareholder made a commitment the following year to provide benefits to all their stakeholders [86].

\subsection{Shareholders Become Accountable for Stakeholders}

However, the BRT made no mention for the need to also introduce "A new model of corporate governance". CEO's accountable to all stakeholders can become accountable to no one. This led some commentators [90] like Pistor to state that: "America's corporate leaders believe they can decide freely to whom they serve." A careful review of Figure 1 reveals that while stakeholder 
interests are represented in an influential manner, shareholder primacy is maintained to make shareholders accountable for protecting and furthering the interest of all other stakeholders. Achieving this objective would make corporations not only a common good but align their purpose in promoting the common good both locally and globally.

Figure 1 allows corporations to be become ethical [91]. In this way it creates the solutions identified in the right hand column of Table 1. Ecological governance also directly increases the wellbeing of individuals by allowing them to constructively use their embedded instincts to introduce checks and balances for spreading organisational self-regulation and self-governance $[9,75]$. How such transformation might be achieved is next considered.

\section{How Can Corporations Become a Common Good?}

\subsection{Tax Incentives}

Elements of ecological governance could be introduced in various ways and stages to publicly traded corporations or other types of organizations in the private, public and/or non-profits sectors. These could arise from:

1. Governing bodies of organizations establishing a requisite variety of stakeholders advisory panels as shown in Figure 1 with any supporting geographical sub-units that besides increasing the depth and density of cross checking data from managers could also be used to promote Just In Time supplies, Total Quality Control for customers, Innovations by lead customers and/or users, employee voice (including anonymously to facilitate whistle blowers) and host community environmental and other feedback advice. Executives would be become accountable for making the entity a common good entity as proposed by the US BRT [86].

2. Governing bodies establishing the above processes in formal regulations of the organization to facilitate the establishment of contestability, challenged, feedback and organizational Tensegrity to promote continuous evolutionary improvements. Directors would become accountable for making the entity a common good entity.

3. Shareholders and/or members changing the constitution of their entity to introduce the arrangements outlined above to make shareholder and/or members accountable for transforming their entity to promote the common good with a "new model of corporate governance" such as proposed by Fink [89].

4. Regulators mandating changes in corporate constitutions as above and/or

5. The government providing tax, and/or other incentives to implement the above processes with and/or without ecological ownership to create common good enterprises that also reduces inequality by democratizing the wealth and control of nations bottom-up.

Ecological governance enriches democracy by directly engaging with broad constituencies of voting stakeholders. This is why it is important that only voters are recognized as stakeholders, not corporate entities with who they may be associated as employees, contractors or agents. It is by this means that democracy becomes enriched with a supplementary political process for individual voter to directly engage and participate in influencing institutions in the private, nonprofit and government sectors. While Figure 1 maintains shareholders primacy, this can be extended to all stakeholders by introducing an ecological form of capitalism $[12,51,53,54,55$, $56,59,62,71,92,93]$ that transfers ownership from shareholders to stakeholders after the time horizon of investors. 


\subsection{Democratising the Wealth and Control of Nations}

The author's book, Democratising the wealth of nations, [92] was not about governance but ownership. It introduced the idea of Ownership Transfer Corporations (OTCs) as a way of creating an economic and political incentive for individual voters to become engaged in reforming capitalism ${ }^{2}$.

At the suggestion of the founder of the UK conservative Think Tank ResPublica the author changed the name of OTC's to the more politically nuanced language of "Endowment Corporation" [71]. A short summary of the 1975 book was published by politically left Australian Think Tanks forty years after its publication [94]. Academic presentations of the idea of replacing exclusive, static and perpetual property rights with inclusive, dynamic and time limited rights are presented $[12,51,93,95]$ with the 1997 article republished in the Corporate Governance volume of This History of Management Thought [51].

The Central Research Institute for National Economy in Prague translated articles of the Author for his visits in 1991 and 1992 [52, 54, 55, 96]. In 1992 the State Commission for Reform of the Economic System hosted the author in Beijing to make presentations on using employee ownership as a technique for privation $[53,96]$.

The host was Professor Jiang Yiwei, an elected deputy to the National People's Congress and a member of its law committee. Yiwei had visited Yugoslavia in 1983 with his finding published the following year in China [98] on Yugoslavian worker self-management initiatives. Yiwei had promoted employee ownership in China in his 1988 book. The text of the book "From enterprisebased economy to economic democracy" was in both Chinese and English [99].

\subsection{All Investments Except Land Have Limited Life}

The majority of all business investments are time limited. Time limited property rights are not an alien, nor a provocative concept for venture capitalists and professional investors. A fact illustrated by the many Build Own, Operate and Transfer (BOOT) projects around the world. All intellectual property rights are time limited. A major intellectual problem is created by accountants assuming all business remain a "going a concern".

So unlike professional investors, accounting doctrines do not have time horizons. This means that investors can get overpaid receiving a cash return back after their time horizon. Any such return is by definition in excess of their incentive to invest to create a "surplus" profit. This is different and additional to any "super", "excessive" or "monopoly" profit that may be received and reported before their time horizon.

What is not reported is not managed, let alone taxed. As reported in the author's initial article [95] surplus profits can be many times greater than the value of the original investment. However, economists assume that there is no limit to greed. This denies them possessing a concept or word to describe profits in excess of the incentive to invest.

\footnotetext{
${ }^{2}$ The book was published by the politically right Company Directors Association of Australia and launched and reviewed by a socialist Dr. Jim Cairns in 1975. Cairns had a PhD in economics and at the time was the Deputy Prime Minister of Australia. His favorable review was published in the Journal of Australian Stockbrokers [114] providing evidence of the books bipartisan appeal. The publisher of the book had added an alternative title for their members being "New money sources and profits motives". Copies were sent to all members of parliament with a different covering letter that used the title most suited for the views of the recipient.
} 


\subsection{Surplus Profits Not Reported}

Surplus profits are an invisible and insidious systemic source of the inequality created by capitalism not considered by economists like Picketty [100]. As surplus profits cannot be measured, the best way of making the economy more efficient and fairer is to introduce dynamic property rights to democratize the wealth of towns, cities, regions and nations [101-103]. Techniques for democratizing urban commons described in [92] and subsequent literature archived by the New Garden Cities Alliance [104].

As corporations are typically taxed at a lower rate than many citizens and have ways to shift profits to tax havens, the transfer of corporate equity to individuals can generate increased tax revenues and votes for political leaders. As shown in [51,92, Appendix] only a relatively small tax incentive is required to provide investors with a bigger, quicker and less risky profits in return for gradually giving up ownership over the twenty year life a patent of say twenty years.

The endowment process can occur by shareholders agreeing to change their corporate constitutions to create a new class of Stakeholders shares. There is not limit to how many stakeholders shares can be issued but the percentage equity endowed each year can be constant. A process is established for any type of stakeholders shown in Figure 1 to become shareholders in a company that maintains shareholder primacy. The author's book [92] suggests a proportion of stakeholders shares are reserved to fund a minimum universal wellbeing income described as a "Social Dividend".

Endowment corporations would payout all their profits each year like many cooperatives. Business growth, management and investor succession could be provided for through dividend re-investment in "offspring" enterprises. Giant corporations would become replaced with nested networks of locally owned and controlled enterprises of human scale as illustrated by the MCC. Investors "fading out with a profit" $[105,106]$ would retain pre-emptive rights to continually be a shareholder in such networks of their choice.

\section{Conclusions}

Any incentive introduced to democratize the wealth of nations could also be used to democratize the control of corporate capitalism as indicated in Figure 1. This would enrich democracy on a bottom up basis with ecological governance. This would make self-governance practical to provide an additional way to reduce the size, cost and influence of governments [9, 107].

Perhaps the most challenging problem in countering climate change is educating both democratically elected leaders and those leading other nations in self-perpetuating command and control hierarchies that neither markets nor hierarchies are sufficient, or even necessary. This problem requires a compelling proportion of the general population to demand changes as outlined above. The challenge for universities it to initiate educational courses at all levels of society to facilitate decision-making.

The economics Nobel Prize Committee have done their part in recognizing Elinor Ostrom in 2009 for sharing the knowledge of organizing collective action to avoid tragedies of the commons. It is ironic that she shared the award with Oliver Williamson who spent his life researching "Markets and Hierarchies" [31].

Markets are the cause of the problem as noted by a former Chief Economist of the World Bank. As Lord Stern he reported to the UK government that: "climate change is the result of the biggest market failure the world has ever seen" [108]. This is because markets did not price the pollution 
cost of burning carbon. Carbon taxing and trading provide a way to counter market failure but stop markets creating counter productive messages.

\subsection{Countering Climate Change by Transforming Markets and Hierarchies}

To avoid markets creating messages to exacerbate climate change the definition of economic value needs to become by defined by the degree each bioregion of the world becomes sustainable for eternity. In other words the value of money in each region needs to be tethered to a Sustainable Index for each region [109-113] Hierarchies inhibit countering the problem of climate change as educational institutions and monotheistic religions unwitting reinforce the belief, that hierarchies are the natural of things. The opposite is the truth. As described by Hock [41, p.7]:

Industrial Age, hierarchical command and control pyramids of power, whether political, social, educational or commercial, were aberrations of the Industrial Age, antithetical to the human spirit, destructive of the biosphere and structurally contrary to the whole history and methods of biological evolution. They were not only archaic and increasingly irrelevant; there were a public menace.

Action research is required to test how best to introduce elements of ecological governance to institutions in the private, government and non-profit sectors. The immediate limitation is that no known graduate schools provide education in how to become a governance architect to lead implementation action. The biggest challenge is to disseminate this knowledge of how to sustain humanity on the planet.

\section{ACKNOWLEDGEMENTS}

The author would like to thank the Reviewers for their constructive suggestions.

\section{REFERENCES}

[1] Garratt Hardin, (1968) 'The tragedy of the commons', Science, Vol. 162, pp. 1243, 1244-1245.

[2] Vincent Ostrom, (1987) The Political Theory of a Compound Republic: Designing the American Experiment, Lincoln, NE, University of Nebraska Press.

[3] Elinor Ostrom (1990) Governing the Commons: The Evolution of Institutions for Collective Action, Cambridge University Press.

[4] Elinor Ostrom (1993) "Self-Governance, the Informal Public Economy, and the Tragedy of the Commons." In: Institutions of Democracy and Development. P.L. Berger, ed. San Francisco: ICS Press.

[5] Elinor Ostrom (1998) 'Scales, polycentricity, and incentives: Designing complexity to govern complexity', In: Protection of Global Biodiversity: Converging Strategies. L.D. Guruswamy \& J.A. McNeely, eds. Durham, NC: Duke University Press.

[6] Elinor Ostrom (1998) 'Self-Governance of Common-Pool Resources,' In: The New Palgrave Dictionary of Economics and the Law, Vol. 3. P. Newman, ed. New York: Stockton.

[7] Elinor Ostrom (2010) 'The Challenge of Self-Governance in Complex Contemporary Environments.' The Journal of Speculative Philosophy 24(4): 316-332

[8] Elinor Ostrom (2012) 'The Challenges of Achieving Conservation and Development.' In The Annual Proceedings of The Wealth and Well-Being of Nations, 2011-2012, Volume IV: Self-Governance, Polycentrism, and the Social Order: Ideas and Influence of Elinor Ostrom. E. Chamlee-Wright, ed. Beloit, WI: Beloit College Press.

[9] Elinor Ostrom, Robert Walker \& Roy Gardner (1992) The Political Theory of a Compound Republic: Designing the American Experiment, Plymouth, UK, Lexington Books

[10] Scott J. A. Kelso, Guillaume Dumas, \& Emmanuelle Tognoli, (2013) 'Outline of a General Theory of Behavior and Brain Coordination', Neural News, 37, pp. 120-131. 
[11] Shann Turnbull, (1991) Economics and the laws of nature, presented to Australian Conservation Foundation, 28 October. In: Allen Marston, ed. (1992) The Other Economy: Economics nature can live with, p. 39, Introduction pp. 3-60, Learn by doing publishers: Auckland, New Zealand.

[12] Turnbull, S. (2015) 'Sustaining society with ecological capitalism', Human Systems Management, 34 17-32, https://content.iospress.com/download/human-systems-management/hsm0831?id=humansystems-management\%2Fhsm0831.

[13] Shann Turnbull, \& Kent Myers, (2017) 'Shaping global cooperation with ecological governance', entry dated September 29th to the "Global Challenge - A new shape: Re-modelling global cooperation", https://papers.ssrn.com/sol3/papers.cfm?abstract_id=3103450.

[14] Shann Turnbull, (2002) The science of corporate governance. Corporate Governance: An International Review, 10(4): 256-272, http://ssrn.com/abstract_id=316939

[16] John, von Neumann, (1947) Theory of games and economic behaviour. CT: Yale Univerity Press.

[17] Claude, E. Shannon, (1949) The mathematical theory of communications, 1-94, Urbana, IL: The University of Illinois Press.

[18] W. Ross Ashby, (1957) An introduction to cybernetics. London: Chapman \& Hall, <http://pespmc1.vub.ac.be/books/introcyb.pdf>.

[19] Ray Kurzweil, (1999) The age of spiritual machines: When computers exceed human intelligence. New York: Viking.

[20] Michael Pirson, \& Shann Turnbull, (2011) Corporate governance, risk management, and the financial crisis - An information processing view. In: Corporate Governance: An International Review, 19(5): 459-470, available from: <http://onlinelibrary.wiley.com/doi/10.1111/j.14678683.2011.00860.x/abstract>.

[21] Michael Pirson, \& Shann Turnbull, (2011) Towards a more humanistic governance model: Network governance structures. Journal of Business Ethics, 99(3): 238-263.

[22] Michael Pirson, \& Shann Turnbull, (2012) A new approach to fix broken governance. ISEI Insight 13: 28-35, available from: <http://www.ieseinsight.com/doc.aspx?id=1366\&ar=3>.

[23] Michael Pirson, \& Shann Turnbull, (2015) The future of corporate governance: Network governance - a lesson from the financial crisis. Human Systems Management, 34(1): 81-89.

[24] Michael Pirson, \& Shann Turnbull, (2016) Decentralized governance structures are able to handle CSR induced complexity better, Business and Society, 1-31, DOI: 10. http://ssrn.com/abstract=2709413.

[25] Shann Turnbull, \& James Guthrie, (2019) 'Holacracy - How Extinction Rebellion's success in organising protests is based on management science', Long Finance, November 1, https://www.longfinance.net/news/pamphleteers/holocracy-how-extinction-rebellions-successorganising-protests-based-management-science/.

[26] Shann Turnbull, \& James Guthrie (2019) 'Simplifying the management of complexity: As found in nature', Journal of Behavioural Economics and Social Systems, 1(1): 51-73, https://papers.ssrn.com/abstract_id=3474786.

[27] Shann Turnbull, \& Michael Pirson, (2019) 'The future of management: network governance', The European Financial Review, May 1, pp. 45-50, http://www.europeanfinancialreview.com/the-futureof-management-network-governance/.

[28] Factbook (2019) The physics factbook, 'Power of a Human Brain',9

[29] The Economist (2020) 'Technology Quarterly: Artificial intelligence and its limits', 13th June.

[30] Ronald, H. Coase (1937) 'The Nature of the Firm', Economica, 4(16), p. 403, https://onlinelibrary.wiley.com/doi/pdf/10.1111/j.1468-0335.1937.tb00002.x

[31] Oliver, E. Williamson, (1975) Markets and Hierarchies: Analysis and antitrust implications, Free Press, New York..

[32] John Mathews, (1996) Holonic organisational architectures. Human Systems Management, Vol. 15, pp. 27-54.

[33] Buckminister Fuller, (1961) 'Tensegrity', Portfolio and Art News Annual, No.4 http://www.rwgrayprojects.com/rbfnotes/fpapers/tensegrity/tenseg01.html

[34] John Pound, (1992) Beyond takeovers: Politics comes to corporate control. Harvard Business Review, March-April, pp. 83-93.

[35] John Pound, (1993) The rise of the political model of corporate governance and corporate control. New York University Law Review, Vol. 68, no. 5, pp. 1003-1071.

[36] Donald, E. Ingber, The architecture of life, Scientific American, pp. 30-39, January

[37] David, Bohm, (1980) Wholeness and the implicit order, Routledge \& Kegan Paul: London. 
[38] Shann Turnbull, (2000) The governance of firms controlled by more than one board: Theory development and examples. PhD Thesis, Macquarie Graduate School of Management, https://papers.ssrn.com/abstract_id=858244.

[39] Norbert, Wiener (1948) Cybernetics: Or Control and Communications in the Animal (and the Machine, Cambridge, MIT Press.

[40] Arthur Koestler, (1967) The ghost in the machine, London: Hutchinson.

[41] Dee Hock, (1995) The Chaordic Organization: Out of Control and Into Order, World Business Academy Perspectives, Vol. 9, No. 1, p. 7, https://www.ratical.org/many_worlds/ChaordicOrg.pdf

[42] Jan Smuts (1925) Holism and evolution. London \& New York: Macmillan.

[43] Herbert, A. Simon, (1962) The architecture of complexity, Proceedings of the American Philosophical Society, Vol. 106, pp. 467-482.

[44] Dee Hock, (1999) Birth of the Chaordic Age, Berrett-Koehler Publishers, San Francisco.

[45] Stafford Beer (1959) Cybernetics and management. English University Press; London.

[46] Stafford Beer (1995) Brain of the firm, 2nd edn, John Wiley \& Sons, Chichester: England.

[47] Stafford Beer (1994), Beyond dispute. John Wiley \& Sons Inc: New York City.

[48] Angela Espinosa, \& Robert Hardin (2007). Team syntegrity and democratic group decision-making: Theory and practice, Journal of the Operational Research Society, Vol. 58, pp.1056-1064, August, https://www.tandfonline.com/doi/abs/10.1057/palgrave.jors.2602261?journalCode=tjor20

[49] Shann Turnbull, (1995) Innovations in corporate governance: The Mondragón experience', Corporate Governance: An International Review, Vol. 3, No. 3, pp. 167-180, http://papers.ssrn.com/sol3/paper.taf?ABSTRACT_ID=6455

[50] Michael, C. Jensen, (1993) The modern industrial revolution: Exit and the failure of internal control systems, The Journal of Finance, Vol. 48, No.3, pp. 831-880.

[51] Shann Turnbull, (1997) Stakeholder Governance: A cybernetic and property rights analysis, Corporate Governance: An International Review, Blackwell, Vol. 5, No. 1, pp. 11-23, http://papers.ssrn.com/sol3/paper.taf?ABSTRACT_ID=11355

[52] Robert Monks, \& Allan Sykes, (2002) Capitalism without owners will fail: A policy maker's guide to reform, New York, Centre for the study of financial innovations, Vol. 57 November.

[52] Shann Turnbull, (1991) 'Property Rights and Markets', in: Economic Alternatives for Eastern Europe Briefing No. 6, New Economics Foundation, London.

[53] Shann Turnbull, (1991) 'Re-inventing Corporations', Human Systems Management, Vol. 10, No. 3, pp. 169-186.

[54] Shann Turnbull, (1991) 'Socialising Capitalism', in: Stuart M. Speiser, ed., Equitable Capitalism: Promoting Economic Opportunity Through Broader Capital Ownership, Chapter 9, pp 97-113, New Horizons Press: New York,

[55] Shann Turnbull, (1991) Statická Nebo Dynamnická Vlastnická Práva (Static or Dynamic Property Rights?) Central Research Institute for National Economy, Prague, Kveten,

[56] Shann Turnbull, (1993) 'Democratic Capitalism; Self-financing local ownership and control', Human Systems Management, 12(4): 333-348

[57\} Shann Turnbull, (1993) 'Flaws and Remedies in Corporatisation and Privatisation', Human Systems Management, Vol. 12, No. 3, pp. 227-252.

[58] Shann Turnbull, (1995) 'Best practices in the governance of GBEs', in: J. Guthrie, ed. Making the Australian Public Sector count in the 1990s, pp. 99-109, IIR Conferences: Sydney.

[59] Shann Turnbull, S. (2000) 'Stakeholder Governance: A cybernetic and property rights analysis'. In: R. I. Tricker, ed. Corporate Governance: The history of management thought, pp. 401-413, Ashgate Publishing: London.

[60] Shann Turnbull, (2000) 'Corporate Charters with Competitive Advantages', St. Johns Law Review, Vol. 74, No. 44, pp. 101-159, http://papers.ssrn.com/sol3/paper.taf?ABSTRACT_ID=10570.

[61] Shann Turnbull, (2001) 'The competitive advantage of stakeholder mutuals': In The New Mutualism in Public Policy, ed. J. Birchall Chapter 9, pp. 171-201, Routledge, London. http://ssrn.com/abstract=242779

[62] Shann Turnbull, (2002a) A new way to govern: Organisations and society after Enron. New Economics Foundation, London, https://papers.ssrn.com/abstract_id=319867

[63] Shann Turnbull, (2005) 'The use of bytes to analyse complex organizations'. In: Kurt Richardson, ed., Managing the Complex: Philosophy, theory and applications, Chapter 9, pp. 152-165, Charlotte, NC: Information Age Publishing Inc., http://ssrn.com/abstract=645281 
[64] Shann Turnbull, (200a) 'The Science of Governance: A Blind spot of risk managers and corporate governance reform', Journal of Risk Management in Financial Institutions, Vol. 1, No. 4, pp. 360368.

[65] Shann Turnbull, (2012) 'Discovering the "natural laws" of Governance'. In: ed. Ralph Ward, The Corporate Board, March/April, Vanguard Publications Inc.: Okemos, MI, http://ssrn.com/abstract=2062579

[66] Shann Turnbull, (2012) 'The limitations in corporate governance best practices'. In Thomas Clarke \& Douglas Branson, eds. Handbook of Corporate Governance, Chapter 19, pp. 428-449, Sage: London \& Thousand Oaks, CA, http://ssrn.com/abstract=1806383

[67] Shann Turnbull, (2013a) 'Achieving environmental sustainable prosperity’. In: Karagiannis Nikolaos \& John Marangos, eds, Toward a Good Society in the Twenty-first Century: Principles and Policies, Part II Sustainability, Ecology, and Good Society, Chapter 4, pp. 75-103, New York, NY: Palgrave Macmillan, http://ssrn.com/abstract=1769349

[68] Shann Turnbull, (2013) 'A sustainable future for corporate governance theory and practice' in S. Boubaker, Bang D. Nguyen \& Duc K. Nguyen, eds. Corporate Governance: Recent Developments and New Trends, pp. 347-368, Springer-Vertag, Heidelberg, http://ssrn.com/abstract=1987305

[69] Shann Turnbull, (2013) 'A transaction byte paradigm for researching organizations'. In: Giulia Mancini \& Mariarosalba Angrisani, eds., Mapping Systemic Knowledge, pp. 243-267, Lambert Academic Publishing, Germany, http://www.volsu.ru/download.php?id=00000031271-1.pdf

[70] Shann Turnbull, (2013) 'How can non-profit organizations enhance performance and legitimize their operations? Presented to: 9th European Institute for Advanced Studies in Management, University of Lund, Sweden, June 13-14, http://ssrn.com/abstract=2223032

[71] Shann Turnbull, (2014a) 'A proposal for self-governing corporations'. In: Philip Blond, ed., The Virtue of Enterprise: Responsible Business for a New Economy, pp. 52-54, January, ResPublica: London, http://www.respublica.org.uk/wp-content/uploads/2014/01/jae_The-Virtue-of-Enterprise.pdf

[72] Shann Turnbull, (2014b) Designing resilient organisations: With operating advantages for public, private, non-profit and government entities and their stakeholders, Lambert Academic Publishing: Saarbrücken, Germany. https://papers.ssrn.com/sol3/papers.cfm?abstract_id=2473393

[73] Shann Turnbull, (2015) Introduction to the Practices, Science, and Art of Designing Corporate Charters, https://vimeo.com/137118382/1d7e82ce27

[74] Shann Turnbull, S. (2016) 'Defining and achieving good governance', in Güler Aras \& Coral Ingley (eds.), Corporate Behavior and Sustainability: Doing Well by Being Good, Chapter 13, pp. 232-249, Ashgate Publishing Ltd., UK, http://ssrn.com/abstract=2571724

[75] Shann Turnbull, (2018) 'A vision for an eco-centric society and how to get there', The Ecological Citizen, Vol. 1, No. 2, pp. 141-142, http://www.ecologicalcitizen.net/pdfs/Vol\%201\%20No\%202.pdf.

[76] Shann Turnbull, (2019) 'Causes and solutions for misconduct in financial services industry,' Law and Financial Markets Review, Vol. 13, Nos. 2-3, ppl 99-113, 16 April, https://doi.org/10.1080/17521440.2019.1602694

[77] ShannTurnbull, (2019) 'How shareholders, corporations and directors can become ethical', The European Financial Review, September 1, pp. 28-32, https://www.europeanfinancialreview.com/howshareholders-corporations-and-directors-can-become-ethical/.

[78] Paul Berstein, (1980) Workplace democratization: Its internal dynamics, Transaction Books: New Brunswick, New Jersey.

[79] Beth Givens, (1991) Citizen utility boards: Because utilities bear watching, Centre for public interest law, University of San Diego, School of law, California.

[80] Torsten, T. Persson, Gerard Roland \& Guido Tabellini, (1996) Separation of powers and accountability: Towards a formal approach to comparative politics. Innocenzo Gasparini Institute for Economic Research (IGIER), Working Paper, No. 100, July, Milan.

[81] Shann Turnbull, (2002) 'Watchdog Boards: Past, Present and Future?' Working Paper, February, http://papers.ssrn.com/abstract_id=608244

[82] Lyn, L. Dallas (1988) 'Two models of corporate governance: Beyond Berle \& Means', Journal of Law Reform, University of Michigan, Vol. 22, No. 1, pp. 19-116.

[83] Lyn, L. Dallas (1997) 'Proposals for reform of corporate boards of directors: The dual board and board ombudsperson', Washington and Lee Law Review, Winter Vol. 54, No. 1, pp. 92-146.

[84] Daniel Diermeier, \& Roger B. Myerson, (1999) 'Bicameralism and its consequences for the internal organisation of legislatures., The American Economic Review, Vol. 89, No. 5, pp. 1182-1196, https://www.aeaweb.org/articles?id=10.1257/aer.89.5.1182 
[85] Andrew Murray, (1998) Minority report on the company reform review Bill 1997, Parliamentary Joint Committee on Corporations and Securities, March, The Parliament of the Commonwealth of Australia,

https://www.aph.gov.au/Parliamentary_Business/Committees/Joint/Corporations_and_Financial_Serv ices/Completed_inquiries/1996-99/companylaw/report/d01

[86] BTR (2019) 'Business Round Table redefines the purpose of a corporation to promote an economy that serves all Americans', August 9th, https://www.businessroundtable.org/business-roundtableredefines-the-purpose-of-a-corporation-to-promote-an-economy-that-serves-all-americans

[87] Katharina Pistor, (2015) 'Module corporate law', Swiss International Law School, https://www.swissintlawschool.org/sils-ll-m/modules/module-corporate-law/

[88] Shann Turnbull, (2015) Introduction to the Practices, Science, and Art of Designing Corporate Charters, https://vimeo.com/137118382/1d7e82ce27

[89] Lawrence Fink, (2018) 'A sense of purpose', BlackRock letter to CEO's, https://www.blackrock.com/corporate/investor-relations/2018-larry-fink-ceo-letter

[90] Katharina Pistor, (2019) 'Why America's CEOs have turned against shareholders', Project syndicate, 26 August, https://www.project-syndicate.org/commentary/american-ceos-turn-against-shareholderprimacy-by-katharina-pistor-2019-08?barrier=accesspaylog

[91] Shann Turnbull, (2019) 'How shareholders, corporations and directors can become ethical', The European Financial Review, September 1, pp. 28-32, https://www.europeanfinancialreview.com/howshareholders-corporations-and-directors-can-become-ethical/

[92] Shann Turnbull, (1975) Democratising the wealth of nations, Company Directors Association of Australia, Sydney, https://papers.ssrn.com/abstract_id=1146062

[93] Shann Turnbull, (1998) 'Should ownership last forever?' Journal of Socio-Economics, Vol. 27, No 3, pp. 341-363, http://papers.ssrn.com/paper.taf?abstract_id=137382 http://papers.ssrn.com/paper.taf?abstract_id=132108

[94] Shann Turnbull, (2015) 'Winning government with policies for reducing inequality?' Evatt Foundation 25 March http://www.evatt.org.au/news/winning-government-reducing-inequality.html. Republished 2016, Australian Fabian Society Newsletter, 30 April, http://d3n8a8pro7vhmx.cloudfront.net/australianfabians/mailings/322/attachments/original/WGBRI

WLT.pdf?1461754892 and in 2020, June, Search Foundation, https://www.search.org.au/wining_government_by_reducing_inequality_with_less_taxes

[95] Shann Turnbull, (197) 'Time Limited Corporations', Abacus: A Journal of Business and Accounting Studies, Sydney University Press, Vol. 9, No. 1. pp. 28-43, June.

[96] Shann Turnbull, (1990) 'Re-inventing corporations', Journal of employee ownership, law and finance, Vol. 2, no. 4, pp. 109-136. (Re-published in Czech as Podniková Organizace, 1991).

[97] Shann Turnbull, (1991) 'Property Rights and Markets', in: Economic Alternatives for Eastern Europe Briefing No. 6, New Economics Foundation, London.

[98] Jiang Yiewei (1984) The self-determination system and current economic difficulties of Yugoslavia, Industrial Economic Management No. 3.

[99] Jiang Yiwei (1988) From enterprise-based economy to economic democracy, (Trans. Li Zhenguo etc.) Beijing.

[100]Thomas Picketty, (2014) Capital in the Twenty First Century, Arthur Goldhammer (translator), The Belknap Press of Harvard University Press,

[101]Shann Turnbull (2009) 'Affordable housing policy: Not identifiable with orthodox economic analysis', The Icfai University Journal of Urban Policy, Vol. 4, No. 1, pp. 21-43 http://papers.ssrn.com/abstract_id=1027864

[102] Shann Turnbull, 2007, 'A framework for designing sustainable urban communities', Kybernetes: The international journal of systems \& cybernetics, Vol. 36, Nos. 9-10, pp. pp. 1543-1557, October 23, http://papers.ssrn.com/abstract_id=960193

[103]Shann Turnbull, (2017) 'Democratising the wealth of cities: Self-financing urban development', Environment and Urbanisation, Vol. 29, No. 1, pp. 237-250, April, http://journals.sagepub.com/doi/full/10.1177/0956247816685985

[104]NGCA New Garden Cities Alliance 2021, https://gardencities.info/reference-documents/01principles/community-land-bank-clb/community-land-bank-bibliography/

[105]Shann Turnbull, (1974) 'Multinationals: Fading out with a Profit', Development Forum, United Nations, Geneva, p.3, June. 
[106]Shann Turnbull, S. (1975) 'Fading Out with a Profit-Planned Corporate Obsolescence', The Canadian Forum, Vol. 55, No. 651, June, pp.14-16.

[107]Shann Turnbull, 2020, Do we need “A new model of corporate governance?” Working paper, https://papers.ssrn.com/abstract_id=3735205

[108]Lord Stern, (2006) The Economics of Climate Change: The Stern Review, Cabinet Office, HM Treasury, London, http://www.sternreview.org.uk

[109] Shann Turnbull, (1983b) 'Selecting a local currency', Options, June, Australian Adam Smith Club, Sydney. (Republished 1997 as 'Creating a community currency'. In: Morehouse (ed.) pp. 167-177), https://papers.ssrn.com/sol3/papers.cfm?abstract_id=1128862

[110] Shann Turnbull, (2011) 'Options for Reforming the Financial System', in: The IUP Journal of Governance and Public Policy, Vol. 6, No. 3, pp. 7-34, September, http://ssrn.com/abstract=1322210

[111]Shann Turnbull, (2016) 'Terminating currency options for distressed economies', Athens Journal of Social Science,Vol. 3, No. 3, p. 205 http://www.athensjournals.gr/social/2016-3-3-3-Turnbull.pdf

[112] Shann Turnbull, (2018) 'Sustainable Value Money: Why it is needed, how to get it?' In: Sabri Boubaker, \& Duc, K. Nguyen, (eds.), Corporate Social Responsibility, Ethics and Sustainable Prosperity, pp. 413-443, World Scientific Publishing, Singapore, https://ssrn.com/abstract=3022277.

[113] Shann Turnbull, S. (2020) 'Reforming money to rescue economies and the planet', 8 May, Online Opinion, https://www.onlineopinion.com.au/view.asp?article=20885

[114]Jim Cairns, (1976) 'Review of Shann Turnbull's Book - Democratising the wealth of nations', JASSA, The Journal of the Securities Institute of Australia, No. 1, pp. 9-13, https://papers.ssrn.com/sol3/papers.cfm?abstract_id=3346835

\section{AUTHOR}

Dr Shann Turnbull is the Principal of the International Institute for Self-governance. He qualified as an Electrical Engineer in Tasmania, and has a BSc from Melbourne University, and a MBA from Harvard. His PhD from Macquarie University Sydney established the science of governance in any specie. He has worked as a business entrepreneur founding a number of enterprises including two public mutual funds and three firms that became publicly traded. In 1975 he co-authored the world's first educational qualification for company directors and wrote "Democratising the Wealth of Nations". In 1977 he was commissioned by the Australian Government to undertake the first economic analysis of Aboriginals, and in 1991 he advised on employee

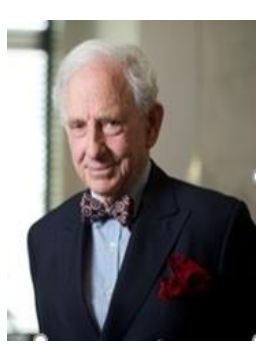
privatisation in the Czech Republic, Slovakia and China. He is prolific author on reforming the theories and practices of capitalism by adopting the practices of nature to achieve sustainability.

(C) 2021 By AIRCC Publishing Corporation. This article is published under the Creative Commons Attribution (CC BY) license. 